Columbia Law School

Scholarship Archive

2008

\title{
Global Network Finance: Organizational Hedging in Times of Uncertainty
}

Katharina Pistor

Columbia Law School, kpisto@law.columbia.edu

Follow this and additional works at: https://scholarship.law.columbia.edu/faculty_scholarship

Part of the Banking and Finance Law Commons, International Law Commons, and the Law and Economics Commons

\section{Recommended Citation}

Katharina Pistor, Global Network Finance: Organizational Hedging in Times of Uncertainty, JouRNAL OF Comparative Economics, Vol. 37, P. 552. 2009; Columbia LaW \& ECONOMics Working PAPER No. 339 (2008). Available at: https://scholarship.law.columbia.edu/faculty_scholarship/2442

This Working Paper is brought to you for free and open access by the Faculty Publications at Scholarship Archive. It has been accepted for inclusion in Faculty Scholarship by an authorized administrator of Scholarship Archive. For more information, please contact scholarshiparchive@law.columbia.edu. 


\title{
Global Network Finance ${ }^{1}$
}

\author{
Organizational Hedging in Times of Uncertainty
}

Katharina Pistor ${ }^{2}$

\begin{abstract}
:
The global financial crisis that began in 2007 revealed a fundamental weakness in the global financial system: Extensive financial interdependence of financial relations unmatched by a governance regime of similar reach. As multinational banks sought to fortify their capital base in the wake of the unfolding crisis, Sovereign wealth Funds (SWFs) and the banks' home governments have become mutual stakeholders in some of the largest financial intermediaries with global reach. From the multitude of individual transactions has emerged a network of equity ties that spans the globe. These ties bridge institutional practices and governance regimes that previously operated largely independently of each other. They have the potential of fostering the emergence of a new governance regime for the global financial market place that deviates from earlier prognoses that globalization entails convergence on a single governance model. Instead, the newly created ties that jointly add up to a global financial network enable institutionally and organizationally diverse players to contribute their own perspectives as joint stakeholders in selected financial intermediaries, and indirectly, in the global financial system. This is likely to have important implications for the behavior of these actors in the future and the emergence of new governance solutions for the global market place. The paper discusses two recent cases of collaborative recapitalization events to illustrate how this regime is evolving in practice.
\end{abstract}

JEL Classification: F36, G2, H8, K2, L22

\footnotetext{
${ }^{1}$ I would like to thank participants at the Summer Conference on Economy and Society in Chicago; the '08 annual meeting of the American Association for Law and Economics; members of the Comparative Law and Economics Forum, and participants at seminars and lectures at Oxford University, ETHZ in Zurich, the University of Amsterdam; Michael Knoll and Anna Gelpern, as well as two anonymous referees for the comments. All remaining errors are mine.

${ }^{2}$ Michael I. Sovern Professor of Law, Columbia Law School.
} 


\section{Introduction}

The paper suggests that this emergent pattern is part of a broader reorganization of global financial markets with important implications for their future governance. Governance in this context is defined as the set of practices and institutions that form the basis for the collective expectations about how to operate in a given environment. ${ }^{3}$ It consists of formal rules and regulations adopted by lawmakers and regulators, but also of practices developed by market participants in response to these rules and regulations. Governance regimes often emerge and collapse without legal change. Conversely, legal change may aspire to shape or change governance, but may fail to do so. Only when law and other formal institutions become part of the collective expectations can one speak of governance, or an emergent governance 'regime'.

The need for a new governance regime for global finance has become apparent with the onset of the credit market crisis of 2007. This crisis revealed several fundamental problems of the existing global financial system. First and foremost, the crisis represents a case of massive market failure as indicated by the rise and fall of the shadow banking system and the inability of market actors to stem the increase of systemic risk. ${ }^{4}$ Secondly, the global financial crisis exemplifies a case of regulatory failure of a similar magnitude, as is evidenced by the patchwork of regulators within and across nation states that competed for attracting finance

\footnotetext{
3 This definition follows Aoki (2001) and Greif (2006) and their emphasis on institutions as actual determinants of behavior.

4 See Martin Wolf, "The Rescue of Bear Stearns marks Liberalisation's Limits", The Financial Times, 26 March 2008.
} 
business, but lacked the political will and legal instruments to contain the systemic risk of interdependent global finance. Thirdly, the immediate policy driven responses to the crisis have been driven primarily by domestic concerns in affected countries with cross-border and global implications of such measures taking second place. Governance mechanisms at the global level were eventually mobilized, but in a rather ad hoc fashion. The meetings of the G20 in November of 2008 and April of 2009 signaled a growing recognition of the importance of global coordination; the organization of this particular group of countries suggest broad agreement that the institutional structures that in the past were mobilized in similar situations - the G8, the BIS, the IMF, and even the Financial Stability Forum (FSF) established in the aftermath of the East Asian financial crisis - were either ineffective or obsolete in their current incarnation. ${ }^{5}$

Historians of financial markets have long argued that the history of financial markets is a history of crises (Kindlegerber, 2005). Equally important, the history of financial crises is the basis too for the history of institutional change and governance reforms in response to such crises. It is no coincidence that the overhaul of the governance regime for securities markets in the United States in 1933-34 was preceded by a stock market crash (Seligman, 1983). In the past, governance solutions have typically been devised at the national level. Even when global agents, such as the IMF or the Bank for International Settlement (BIS), were involved in designing governance regimes, their tasks were largely confined to promoting

\footnotetext{
${ }^{5}$ To be sure, the IMF emerged strengthened from the G20 meeting in London, but any larger role it might play in the future will be contingent on further reforms of its voting arrangements. See The Economist "Banking on the Fund", The Economist, 8 April 2009 (Leader).
} 
standardized solutions that had to be implemented at the national level. An open question is where solutions for a new governance regime will come from this time given the truly global scope of the crisis and given the extent to which the crisis has undermined the credibility of the predominant governance model that preceded it. The most recent international financial market crisis prior to the current global crisis - the East Asian financial crisis of 1997-98 and the subsequent emerging market crises in Russia (1998) and Latin America (2001) — did not face a similar dilemma. At the time it seemed obvious that the institutional solutions should be derived from 'best practices' in developed market economies, spearheaded by the US and the UK (IMF, 1995, IMF, 2003). This belief formed the basis for policy advice by the International Monetary Fund (IMF), the World Bank, the US Treasury and others given to afflicted countries. ${ }^{6}$

In the current crisis, distinguishing between good and bad governance practices has become as difficult as distinguishing between good and bad assets. As Ben Bernanke, chairman of the U.S. Federal Reserve following the announcement of a massive bail out plan by the Federal Government on September 19th, put it, "there are no atheists in foxholes and no ideologues in financial crises". ${ }^{7}$ While the political debate in the US Congress that surrounded the adoption of the "Troubled Assets Rescue Plan" (TARP) ${ }^{8}$ and subsequent measures may suggest otherwise, the lack of

\footnotetext{
${ }^{6}$ Neither the belief nor the policy advice that followed from it was undisputed. For a critical review of the reforms in South Korea following the East Asian crisis, see, for example, Shin and Chang, (Shin and Chang, 2005).

${ }^{7}$ Peter Baker, "A Professor and a Banker Burry Old Dogma on Markets", The New York Times, 20 September 2008, p. A1.

${ }^{8}$ The House of Representative rejected TARP with over 50 percent of Republican voting against it, in part because government intervention on this scale was deemed to be un-American. See "The bail-
} 
a dominant ideological paradigm is one reason for the lack of a simple blue print for a new governance regime. Instead, policy makers have turned to ad hoc measures to stem the fallout from the crisis (Davidoff and Zaring, 2008). The absence of a readymade solution leaves open the question where to look for the material or the actors that will form a new governance regime for global finance.

One place to look is to the actors themselves, that is, to the afflicted financial intermediaries and those that have come to their rescue. These parties did not have the luxury of postponing reforms until a political compromise could be reached, but had to respond to fend off the threat the crisis posed for their future and the future of financial markets. They include private banks from the West, their home governments, and Sovereign Wealth Funds (hereafter referred to as SWFs) from the Middle and the Far East. Beginning in early summer of 2007, a number of SWFs began to take substantial equity (or convertible debt) positions in what at least used to be some of the largest financial intermediaries in the West. In the fall of 2008 SWFs received company from the banks' home governments. As a result of a series of bailout transactions these governments have become sizeable shareholders in large banks located within their respective jurisdiction. ${ }^{9}$ Cumulatively these responses have created a network of equity ties linking the world's largest financial players, i.e. financial intermediaries and sovereign investors 'of last resort', 10

out failure and blame game", The Financial Times Editorial, 30 September 2008, available on www.ft.com.

${ }^{9}$ As part of a recapitalization strategy, the US and the UK government have taken substantial equity positions in several of their largest banks. See infra Part V for details.

${ }^{10}$ In the aftermath of the bail out transactions undertaken by the US government, governments have been recognized not only as lenders of last resort for deposit taking banks, but as investors of last resort for any financial institution that is too large to fail. See Edmund L. Andrews, "A New Role for the Fed: Investor of Last Resort", the New York Times, 18 September 2008, B1. 
effectively giving the latter not only a stake in selected financial intermediaries, but through them-a stake the global financial market. These network relations are therefore likely to affect how these markets will be governed in the future, even if the specific configuration of the network will change or most ties will be severed once the crisis has receded. This is the case, because the new cooperative governance solutions brought about by the crisis have set a precedent and as such are likely to influence the strategic behavior of the actors involved. Put differently, just as formal bankruptcy regimes have important ex ante implications (Bebchuk, 2002), so do informal workout solutions.

Institutional innovation brought about by key actors in the market is a critical mechanism through which the new governance regimes evolve. When the credibility of a governance regime is undermined, as tends to happen in a major crisis, actors hedge not only their financial bets. They also hedge their bets as to what the new 'rules of the game'11 for organizing economic relations might be. David Stark has termed this response to uncertainty about the institutional environment "organizational hedging" (Stark, 1996). Organizational hedging entails establishing relations with actors outside existing communities and established modes of practice. Newly formed relations create an opportunity for sharing information, experience, and practices, from which solutions for new institutions can evolve. ${ }^{12} \mathrm{~A}$

\footnotetext{
${ }^{11}$ Douglas North (North, 1990) refers to institutions as the rules of the game. They include both formal institutions (laws and regulations) and informal institutions (social norms and business practices).

${ }^{12}$ Charles Sabel have coined the term "experimental governance" for similar processes. See (Sabel and Zeitlin, 2006) for an analysis of the evolution of governance in the context of the European Union. See also (Gilson, et al., 2009) for an account of how firms in innovative sectors organize collaborative relations with other firms that are structured to encourage sharing of information and expertise.
} 
new governance regime emerges from this search process when these practices become institutionalized, that is, when they become part of the collective expectations of key players. ${ }^{13}$

While most transactions between banks and SWFs viewed in isolation can be rationalized as financial transactions between two autonomous players-one of which happened to be a SWF-they together with governments that injected additional capital now find themselves in a situation where they have few and potentially costly exit options, both individually and collectively at their disposal. Lest they risk another failure of a major global financial player, this new coalition of banks, SWFs and governments is forced to work out governance solutions collaboratively. This coalition bridges diverse systems of governance that previously operated mostly independently of each other. Specifically, SWFs represent a different mode of governance as compared to that endorsed by financial intermediaries in the West, i.e. one that gives government actors a key role in setting aside investment capital and determining strategies for its allocation. Their rise to fame in recent years in and of itself is indicative of the transformation of global financial relations and the hybridization of governance regimes that can no longer be easily categorized as private vs. public; state vs. market; transactional vs. relational, et cetera. The most visible evidence for this transformation is the rise of global imbalances between emerging markets that accumulated vast amount of reserves on one hand, and developed economies that accumulated substantial debt, on the other. A substantial proportion of the reserves are held in dollar 
denominated asset, and a substantial part of it was recycled to finance the US's private and public debt. As a result of this symbiotic relation, the rich North has become a net importer of capital (Alberola and Serena, 2008, Prasad, et al., 2007) primarily from exporters of natural resources and tradable goods. The countries that accumulated reserves in return have established new SWFs or directed existing ones to invest more aggressively in assets promising higher returns than US treasury bills; many shifted investments into finance just at the time when financial markets had passed their peak. With hindsight, SWFs (just as other investors) would have been better off had they adhered to the more conservative investment strategies most of them had followed previously (Monitor, 2008). Their foray into global finance at this time exposed them not only to the risk of holding dollardenominated assets, but more seriously, to the risk of a global financial system that found itself on the verge of collapse. This exposure has now positioned them to partake in the search for post-crisis solutions and to build a more sustainable governance regime.

The paper develops this argument in several steps: Part II presents a taxonomy of transactions that has given rise to a global financial network and the actors that participate in them. Part III discusses social and economic theories that emphasize the role of organizations as modes of governance and analyzes the contributions inter-organizational networks can make to governance. Part IV develops the notion that networks can be understood as a form of organizational hedging, which in turn can give rise to institutional innovation and change. Part $\mathrm{V}$ 
presents two case studies that illustrate the new forms of cooperative governance among diverse players in the global financial market place. Part VI concludes.

\section{Taxonomy of Transactions and Actors}

Between May of 2007 and October 2008, a series of transactions were completed between over a dozen banks located in the US and Western Europe and a number of SWFs (see Appendix 1 for details). These initial transactions gave SWFs a substantial minority stake in Western banks. ${ }^{14}$ The total value of the transactions concluded in this first round of investments in 2007-08 did not exceed US\$70bln. ${ }^{15}$ This is a relatively small amount when compared to the total value of investments in financial and non-financial companies made by SWFs within the same time frame (Gerard and Sauvant, 2009). However, the total value may be less relevant than the identity of the players and the pattern of financial relations they gave rise to.

Several participants on both sides of the transactions were repeat players. Among the Western banks that raised capital from more than one SWF, and, on occasion, more than once from the same SWF, were Barclays (Qatar Investment Authority, QIA, Temasek of Singapore, and China Development Bank, CDB); Citigroup (ADIA of Abu Dhabi, Kuwait Investment Authority, and the Government of Singapore Investment Corporation or GIC); UBS of Switzerland (GIC and two unidentified, most likely Saudi Arabian investors from the Middle East), and Merrill

\footnotetext{
${ }^{14}$ Share acquisitions on the secondary market, such as China's SAFE's minority acquisitions of stakes smaller than 1 percent in 50 different UK listed entities have been excluded from the survey.

${ }^{15}$ See the figures in Appendix for details.
} 
Lynch (Temasek, Kuwait Investment Authority, KIA, and the Korean Investment Corporation, KIC). ${ }^{16}$ Each of these banks received capital injections amounting to US $\$ 12$ billion from a single SWF. According to 2007 data, these banks were among the largest financial intermediaries in the world based on asset value. ${ }^{17}$ They were also among the top five financial intermediaries in their respective home countries.

Several SWFs also became repeat players by investing in more than one Western bank. Singapore's Temasek acquired substantial minority stakes in Barclays and Merrill Lynch, after having previously secured a 14 percent stake in Standard Chartered (UK). ${ }^{18}$ Temasek's sister organizations, the government of Singapore investment corporation (GIC), became an important stakeholder in Citigroup and UBS. China's new state investment corporation, CIC, participated in two investments: a 9.9 percent stake in the private equity group Blackstone, and a five percent stake in Morgan Stanley (which it subsequently increased to 10 percent). In addition, it invested US $\$ 3.2$ billion in a distressed asset vehicle managed by the US firm JC Flowers. Kuwait Investment Authority (KIA) invested in Citigroup as well as UBS. And finally, the Qatar Investment Authority (QIA) acquired a minority equity stake in Barclays in June of 2007 and increased this stake

\footnotetext{
${ }^{16}$ As a result of the stock for stock merger between Merill Lynch and Bank of America agreed in September of 2008, the SWFs that had previously invested in Merrill Lynch became shareholders of BofA.

${ }^{17}$ Based on data available from Orbis, as of 2007, Citigroup was the largest and Barclays the $2^{\text {nd }}$ largest bank. Source: Orbis data base.

18 The stake has since been increased to 19 percent.
} 
substantially in the fall 2008; it also invested in Credit Suiss early in 2008, and again in the fall of $2008 .{ }^{19}$

The terms of the transactions that have linked Western banks and SWFs and Western banks have varied. Some transactions were for common stock, others for non-voting equity units, and yet others gave SWFs convertible debt securities with fixed dividend payments. Some of these debt securities made the conversion optional, whereas others provided for mandatory conversion at a fixed future date. ${ }^{20}$ Some had lockup provisions; others inadvertently achieved a similar effect by linking the price for future conversions to the market price at the time of the transaction (which subsequently declined). From a legal perspective these formal features gave SWFs very different positions in the targeted banks. Still, the formal differences might overstate variations in outcomes. Common stock gives investors voting rights. Yet, those transactions that gave SWFs common stock have been for minority stakes only; ${ }^{21}$ minority stakes typically do not translate directly into control even when they confer voting rights. Most minority shareholders are rationally passive; they assert influence over their investment target by threatening with exit or with refusing future investments. Both are potentially viable threats by SWFs, as they have become the largest providers of capital apart from domestic governments in the banks' home country. Nonetheless, the deepening of the crisis

\footnotetext{
${ }^{19}$ Credit Swiss raised new funds from investors located in Qatar, Saudi Arabia and Israel in October 2008. See Lionel Laurant, “Credit Swiss Tops Up”, Forbes, 16 October 2008, available at www.bloomberg.com.

${ }^{20}$ Column 4 of Table 1 lists the different features of the transactions.

${ }^{21}$ An example is Temasek's and CDB's investments in Barclays in the summer of 2007. Interestingly, GIC recently converted the preferred stock it held in Citigroup into common stock. The reasons and implications of this conversion prior to the contractual conversion date will be discussed in detail in Part $\mathrm{V}$ below.
} 
has made exit not an easy option. In the current environment it is difficult to find buyers for large stakes. Moreover, the sale of substantial stakes in a vulnerable bank may trigger broader repercussions in the financial markets. In the post-Lehmann world 22 this is likely to deter actors with a stake not only in individual banks, but in financial markets. Thus, the crisis has imposed a de-facto lockup on SWFs that may persist well beyond the lockup periods they had formally agreed on. By implication, SWFs have a substantial interest in the performance of these banks and are likely to ensure that their voice will heard irrespective of whether or not they command formal voting rights. ${ }^{23}$

The same applies to transactions in which SWFs received convertible debt securities rather than equity stakes. While convertible debt securities guarantee some return in the form of fixed recurrent payments, the real value of the investment is typically determined at the time of conversion. Mandatory convertibility at a fixed future date exposes the investor to the risk that the conversion is preceded by a decline in share price. Only in the case that the conversion takes place after a rise of share value can the investor book a gain. Most of the transactions documented in Appendix 1 were for convertible debt or preferred securities; the shift from common stock to convertibles indicates that with the deepening of the financial crisis SWFs became more concerned about the risk of investing in financial intermediaries in light of what increasingly looked like a

\footnotetext{
${ }^{22}$ Lehmann brothers was allowed to go bankrupt in September 2008, triggering a chain reaction that resulted in governments taking equity stakes in key banks. See (Davidoff and Zaring, 2008).

${ }^{23}$ It is therefore questionable, whether a proposal to restrict voting rights of SWF's would have much of an impact. Such a proposal has been developed by (Gilson and Milhaupt, 2008). For a similar critique see (Gelpern, 2008).
} 
deepening crisis rather than temporary downturn. The target banks in turn agreed to pay a fixed dividend of between 7 and 11 percent per annum - a substantial premium over the going market rate ${ }^{24}$-reflecting the rise in cost of borrowing for financial intermediaries. The high interest rate gave investors some assurance, ${ }^{25}$ however it still left them carrying the risk that the investment would be in the money at the time of conversion. ${ }^{26}$

Transactions between Western banks and government controlled financial intermediaries are not entirely new. When China partially privatized its largest banks in 2005-06, a number of Western banks acquired large minority stakes; these banks included Morgan Stanley, Citigroup, Goldman Sachs, UBS, and RBS, as well as Bank of America. In 2007-08 most of them received SWFs investments as well as capital injections from their respective home governments. ${ }^{27}$ The transactions between Western banks as investors and Chinese state controlled banks share many features with the SWF/Bank transactions described above: Investors acquired substantial minority stakes often with lockup provisions (Leigh and Podpiera, 2006). Typically more than one foreign financial intermediary invested in the same

\footnotetext{
24 The Fed's interest rate as of December 2007 was $4 \frac{1}{4}$ percent. See http://www.federalreserve.gov/newsevents/press/monetary/20071211a.htm. 25 Note, however, that GIC agreed to convert its shares in Citigroup into common stock at a much earlier date and a price far below the original purchasing price as part of the recapitalization effort of Citigroup in February 2009.

${ }^{26}$ An example for the risk SWFs encountered is Citigroup. ADIA, the SWF of Abu Dhabi (UAE) invested over US $\$ 7 \mathrm{bn}$ in Citigroup in late 2007 in return for convertible debt bearing an 11 percent interest rate (equivalent to junk bond status). According to the original agreement, the debt had to be converted into equity between March 2010 and September 2011 at a price of between $\$ 31.83$ and $\$ 37.24$ a share. By February 2009, Citigroup's share price was trading at only US $\$ 1.50$ per share. See Stanley Cavalho, "Abu Dhabi reviewing Citigroup investment", Reuters, 1 March 2009, available at www.reuters.com.

${ }^{27}$ Goldman Sachs was the only financial intermediary among them that did not receive SWF rescue funds (although it counted SWFs among its dispersed investors). Nonetheless, it did receive US government bailout funds.
} 
bank. Viewed in this light, the SWF investments in Western banks can be described as the mirror image of these earlier transactions (Pistor, 2009). In the fall of 2008, the network was extended to include Western governments of those banks that required a government bail-out implicating the governments of the US, the UK, and Switzerland (see Figure 1 below). Some of the ties have been severed since. However, while the shape of the network has changed as a result, its basic configuration as a global financial network has not (see Figure 1 below).

\section{[INSERT FIGURE 1 ABOUT HERE]}

As the previous discussion suggests, the network has grown in waves. The first wave in 2005/06 comprised of investments by Western banks in Chinese banks; the second, starting in 2007, of SWFs from China, Singapore and several oil exporting countries in the Middle East investing in Western banks. The third wave which began late in 2008 and continued through early 2009 witnessed the home country governments of the same bank bailing them out and in the process sometimes becoming a controlling shareholder in these banks. ${ }^{28}$ While this suggests a rapid expansion of GNF in the course of the deepening financial market crisis, several consolidations as well as partial exits have also taken place.

Exits may indicate the inherent fragility of GNF and thus deserve closer scrutiny. The exits that have occurred so far are closely associated with a merger or takeover (including by a bank's home government), the expiration of explicit lockup

${ }^{28}$ The UK government in RBS and Lloyds; the US government now holds common stock in excess of 30 percent in Citi, which technically makes it the largest, but not a controlling shareholder. 
provisions in the original investment deals, or a combination of both. In most cases where ties have been severed the entities remained part of the network through ties with other network members. RBS and UBS sold their stakes in Bank of China (BoC) upon expiration of the three-year lockup at the end of December 2008. At the time of their exit both banks had received extensive bail-out funds from their respective home governments. The UK government already owned a 70 percent share in RBS, a stake it subsequently increased to 75 percent. ${ }^{29}$ The Swiss government acquired a 9.3 percent stake in UBS in return for a capital injection of US\$ 6 billion. ${ }^{30}$ The decision to sell the stake in BOC was triggered by the need of these two banks to raise fresh capital after having suffered substantial write-downs. In contrast, when BofA's lock-in period for its investment in CCB expired in late October 2008, BofA decided to take advantage of the relative depressed price of CCB's shares at the time and instead exercised an option to increase its stake to 19.1 percent. ${ }^{31}$ BofA apparently planned from the outset to sell a substantial part of its original stake, however, it deferred this transaction by several weeks after the intervention of CCB's CEO, Guo Shuqing; ${ }^{32}$ Chinese authorities were nervous at the time that an accelerated sell off by Western banks in need of cash might deflate share prices of

\footnotetext{
${ }^{29}$ Jill Treanor, "RBS record losses raise prospect of 95\% state ownership", The Guardian, 26 February 2009, available at www.guardian.co.uk.

${ }^{30}$ In addition, a substantial part of UBS' non-performing assets were moved to a fund sponsored by the Swiss National Bank (SNB), Switzerland's central bank, which is co-financed by UBS and the SNB. See BBC, "Switzerland unveils UBS bailout", BBC News, 16 October 2008, available at http://news.bbc.co.uk/2/hi/business/7673159.stm.

${ }^{31}$ Daniel Inman, "BofA increases stake in CCB", Finance Asia available at http://www.financeasia.com/article.aspx?CIaNID=89289.

32 Sundeep Tucker and Jamil Anderlini, "BofA shelves plan to cut CCB stake”, The Financial Times, 19

December 2008, available at www.ft.com.
} 
their own banks. ${ }^{33}$ The fact that BofA deferred the sale of its stake marks an interesting departure from a purely profit maximization strategy. It suggests that BofA chose not to be oblivious to the impact the sale of its stake in CCB might have on China in the volatile market conditions of late 2008. BofA eventually sold three percent in CCB in January 2009 in a private placement that were picked up by Chinese investors; in May 2009, after the stress test the US government had conducted for all major banks revealed that BofA was in need of additional capital, it sold the remaining shared it had acquired in 2005 for over US\$ 7 billion. ${ }^{34}$ However, this still leaves BofA still with the $10 \%$ stake, which is subject to a three-year lockup. Other changes in the network ties resulted from merger activities. When BofA consummated its merger with Merrill Lynch at the end of 2008, Temasek's stake in Merrill was converted into convertible and common stock in BofA. ${ }^{35}$ Temasek sold its stake in BofA in May 2009 amidst announcements that it was refocusing its investment strategy on emerging markets. ${ }^{36}$ Indeed, at about the same time Temasek sold its stake in BofA, it participated in a consortium that acquired

\footnotetext{
${ }^{33}$ Interview with executive from CIC in December 2008 who suggested that CIC and its subsidiary Hui Jin were in active negotiations with all foreign investors seeking to dissuade them from selling their stake. Interview notes on file with the author. Confirming its preference for stable owners of its banks, the Chinese government announced in May 2009 that future investors in China's financial intermediaries would face a 5-year lockup period. See Jamil Anderlini, "China extends banks lock-up", The Financial Times, 1 April 2009, available at www.ft.com.

${ }^{34}$ Sundeep Tucker, "BofA raises US\$ 7.3bn in China bank stake sale", The Financial Times, 13 May 2009, available at www.ft.com.

${ }^{35}$ According to BofA filings with the US Securities and Exchange Commission, each share of common stock in Merrill Lynch was converted into 0.8595 shares of BofA. Moreover, the "Non-Voting Mandatory Convertible Non-Cumulative Preferred Stock, Series 2, and 9.00\% Non-Voting Mandatory Convertible Non-Cumulative Preferred Stock, Series 3 that was outstanding immediately prior to the completion of the acquisition remained issued and outstanding subsequent to the acquisition, but are now convertible into Bank of America common stock". See 8-K Filings by BofA of 25 February 2008, Exhibit 99.1 "Audited, consolidated balance sheet".

${ }^{36}$ John Burton, "Temasek defends BofA Sale", The Financial Times, 22 May 2009, available at www.ft.com.
} 
most of the shares that BofA sold in CCB; ${ }^{37}$ this transaction is noteworthy, because it suggests that Temasek played a critical role in buffering the impact of the exit by Western investors from Chinese banks. It thereby effectively signaled to Chinese authorities that it was a more reliable investor than its Western counterparts.

While selected network ties have been either dissolved or trimmed down, others have deepened; one case in point is Barclays' private placement of shares with SWFs from Qatar (and a member of the Royal Family of Abu Dhabi) in October 2008. Barclays declined financial support from the UK government it had mad available after the collapse of Lehman Brothers and instead turned to SWFs. Several SWFs had previously invested in Barclays, including QIA, Temasek and CDB. In November 2008, Barclays was pressured by UK regulatory authorities to improve its capital base. Barclays' directors sought and received in a contentious shareholder meeting approval to place additional securities with a consortium of institutional investors spearheaded by an investment vehicle (Challenger) affiliated with QIA. When the warrants and other convertible instruments were converted, they conferred substantial minority stakes to these investors. ${ }^{38}$ In addition, a number of SWFs increased their investments in Western financials, even after suffering substantial losses on the original investment. Examples include Temasek's additional investments in Merrill Lynch before the banks was taken over by BofA; CIC's investment in Blackstone in October 2008, which at least temporarily

\footnotetext{
37 Sundeep Tucker, supra note 30.

${ }^{38}$ Letter by Marcus Agius, Chairman Barclays PLC, to shareholders accompanying the notice of the General Meeting of Barclays on 24 November 2008, available at www.investorrelations.barclays.co.uk. At the time it was estimated that the consortium would jointly own more than $30 \%$ of Barclay's outstanding equity. Note, however, that Sheikh Mansour of Abu Dhabi sold his stake prior to the conversion date. For details see infra under V.
} 
increased CIC's stake in Blackstone to over 10 percent; QIA's, Temasek's and CDB's acceptance of a private placement of shares after Barclays failed to attract sufficient public subscribers in June 2008; and GIC's repeat investments in Citigroup (for details see Appendix 1).

In sum, the global financial network structure depicted in Figure 1 has proven itself remarkably durable under the stress of global financial crisis. This raises the possibility that network relations-even if not a specific network configuration-will become a more permanent feature of the global financial marketplace.

III. Networks and the Organization and Governance of Economic Relations

It is well understood from organizational theory and the comparative corporate governance literature that the organization of economic relations is an important determinant of their governance regime. Concentrated ownership, for example, gives rise to different governance problems than dispersed ownership (Bebchuk, 1999, Gilson, 2006, Morck, 2000, Roe, 1993); moreover, the formation of ownership patterns and inter-firm relations has been related to the governance environment in which they take place. In particular, patterns of concentrated ownership and the emergence of company groups and alliances has been associated with uncertainty in the legal environment (Khanna and Palepu, 2000, Shleifer and Vishny, 1997). Finally, there is evidence that these organizational patterns tend to persist long after the conditions that gave rise to it in the first place may have 
vanished (Bebchuk and Roe, 1999, Franks, et al., 2003); It is therefore critical to understand networks as organizations of economic relations and the particular contribution they make to the governance of such relations.

The emergent global financial network depicted in Figure 1 is a new development in global finance. This section explores the governance potential of GNF drawing on or theories explaining organizations as governance devices. As Coase (Coase, 1937) has suggested in the "Nature of the Firm" not all economic relations are conducted via market relations. Instead, many take place within firms, i.e. in integrated organizations. This has given rise to an extensive literature on the theory of the firm and more generally on the organization of property rights and contractual relations. Specifically, vertical integration of economic relations, i.e. hierarchy, is said to reflect the fact that costs of market transactions may on occasion be prohibitively high (Hart, 1995, Williamson, 1985). In a similar vein, it has been argued that inter-firm relations both respond to governance needs (Granovetter, 1994, Khanna, 2000).

Inter-firm relations come in different forms and different intensity. In the words of Leff, "the group is a multicompany firm which transacts in different markets but which does so under common entrepreneurial and financial control" (Leff, 1978). Typically, the founding owner or family controls the group, but draws on capital provided by outside investors. A common way for combining control with outside capital is the use of pyramid schemes with multiple layers of subsidiaries. ${ }^{39}$

\footnotetext{
${ }^{39}$ At the lowest level of this pyramid the family may hold only a small stake, but by virtue of controlling other subsidiaries, which in turn hold stakes in the entity at the bottom, it nonetheless
} 
GNF differs from an integrated group of this kind. The various nodes in the network are linked primarily by minority stakes and for the most part do not confer control rights. ${ }^{40}$ They do not operate under common management or guidance, nor are they subject to central financial control. And while company groups often combine companies specializing in different products and markets, GNF consists primarily of financial intermediaries. ${ }^{41}$

The concept of 'strategic alliances' depicts a somewhat loser affiliation of firms. Gulati (Gulati, 1998), for example, defines strategic alliances as "voluntary arrangements between firms involving exchange, sharing, or co-development of products, technologies or services". He emphasizes that alliances can "occur as a result of a wide range of motives and goals, take a variety of forms, and occur across vertical and horizontal boundaries" (ibid). According to this definition, any relation among independent entities that involves some collaborative efforts but does not allocated control rights of one member in the alliance over another might be regarded as an alliance. In that sense, it departs from the principle that control, or property, rights are the primary determinants of business organizations (Grossman and Hart, 1986). Strategic alliances have become quite prominent in international business relations, particularly in industries marred by uncertainties, including research and development intensive industries, such as biotech (Robinson and Stuart, 2002). Collaborating firms often forego the possibility of creating joint

exerts control. For details on how to separate control from cash-flow rights in stock pyramids, see (Bebchuk, et al., 2000)

${ }^{40} \mathrm{On}$ the increasing prevalence of large block holdings by SWFs and/or home governments of banks, see below under $\mathrm{V}$.

${ }^{41}$ Some actors in GNF can be described as company groups using Leff's definition. Thus, Temasek has large holdings not only in finance, but also in other sector, such as telecom, shipbuilding and airlines. 
ventures with a clear allocation of rights and responsibilities among themselves in favor of an open-ended commitment to cooperate (Gilson, et al., 2009). This loser governance structure facilitates cooperation as long as both parties gain more from staying put rather than defecting.

Networks resemble alliances in that they too are relatively loose configurations and typically lack a common governance structure. Powell (1990) has made an effort to classify networks as distinct organizational forms that are 'neither market nor hierarchy'. He defines market relations as governed by contracts between actors presumed to be operating at arm's length. Contractual relations are supported and made credible by dispute settlement and enforcement mechanisms, such as courts or arbitration tribunals. Networks also differ from vertically integrated firms, because they lack centralized management. At the same time, networks too are concerned with resource allocation. They accomplish this task in a different manner, however. "In network modes of resource allocation, transactions occur neither through discrete exchanges nor by administrative fiat, but through networks of individuals engaged in reciprocal, preferential, mutually supportive actions. (...) In essence, the parties to a network agree to forego the right to pursue their own interests at the expense of others" (Powell, 1990). Because networks do not confer control to a dominant party, they facilitate the coexistence of diverse entities-whether this diversity is rooted in different governance regimes, objectives or other features. Whereas property rights theories of the firm emphasize the relative costs of market transactions vs. vertical integration as 
function of control over assets (Grossman and Hart, 1986), network theory emphasizes the mutual gains for both parties from cooperating without dominating.

Networks understood as governance devices for cooperative relations can facilitate the expansion of economic activities from an environment with familiar institutions and practices to a new domain with institutional arrangements that are novel for the newcomer. The business sociologist Ronald S. Burt has called the strategic expansion of actors into new and unfamiliar domains the bridging of "structural holes" (Burt, 1995). Economic relations require interaction among different actors. This exchange is facilitated by a common understanding of the 'rules of the game' (North, 1991), which in turn favors actors who share a similar understanding of these rules, i.e. a similar institutional domain. Yet, gains can be made from reaching out and breaching traditional spheres of exchange. An actor can gain access to new information and business opportunities by positioning herself as a link between two or more networks, each with its own membership, practices and governance devices. By implication, this actor can also influence the development of practices in the different networks she participates in. Some actors may indeed strategically situate themselves as bridging nodes between two or more networks. However, in many instances a changing environment induces actors to alter their behavior and defect from established patterns of behavior. In doing so they may not intent to participate in institutional change, but they do so inadvertently.

An example for changing network relations in the context of market integration is the history of the formation of business networks in the United States. Prior to WW II, markets were not fully integrated at the national level. Local and 
regional markets were dominated by strong interest groups, or "cliques" with strong inter-firm relations in the form of stockholdings, debts, and other forms of economic interdependence (Bearden, et al., 1975 as quoted in Granovetter, 1983). In the post WW II era, these strong ties were increasingly crowded out by a new networks comprised of looser ties among actors from different parts of the country. In contrast to local clique relations, these newly formed ties connected actors that did not belong to the same clique and thus had few, if any, pre-existing relations. These "weak ties" (Granovetter, 1973), mostly in the form of repeat business dealings, formed an emergent national, and increasingly international network of firms: The extensive national network is formed from weak ties... they do not imply specific inter-firm economic connections; instead they reflect an overall common orientation and interest, the need for common action across cliques, and a growing sense of national and international interdependence among large corporations ... (Bearden, et al., 1975).

Both the local cliques as well as the emergent looser networks of ties helped shape collective expectations about how to operate in the new environment and thereby contributed to the institutional integration of these markets. The expanding national network changed the expectations of actors who previously had operated primarily at the local level and allowed them to develop new forms of conduct with business partners in the emergent national market. In that sense they performed governance functions.

Viewed in this light, GNF is a response to the collapse of the global financial system and the uncertainties about its future governance regime. Many observers of globalization expected worldwide convergence on the Western model of private 
banking, characterized autonomy from government, and modest regulation (Gilson, 2001, Gordon and Roe, 2004). The global financial crisis has shaken belief in the foundations of the Western model of finance and the perception of its' inherent superiority. This poses new challenges for the parties in the global market and ultimately for its governance. Even if each individual transaction that linked two parties to each other and to the broader network was motivated primarily by commercial concerns (i.e. the need to raise capital and the desire to make profits), the changing economic environment has created conditions under which the maintenance of these ties has become critical for stabilizing key players in global finance.

The potential for finding new solutions has been enhanced by the fact that the network relations that form GNF have bridged 'structural holes' between different markets and governance regimes. Prior to the emergence of GNF, banks and SWFs operated in distinct environments, each embedded in their own institutional environment and network relations, but with few linkages among tem. SWFs operated as investment arms of their respective governments who controlled their finances and determined their governance, sometimes even specific investment decisions (Hammer, et al., 2008). Private banks used to operate at greater autonomy from their home governments and in an increasingly de-regulated environment. Finally, host governments of banks performed largely monitoring and basic regulatory functions. However, they did not participate directly in financial intermediation and resource allocation and neither did they have direct say in the firm-level governance of private intermediaries that performed such functions. 
Rather than relying on market forces to produce the most efficient organizational outcome, the focus of involved parties has shifted to creating conditions for coexistence of and mutual learning from alternative models. Network relations can facilitate this process. Banks, their home governments, and SWFs have become costakeholders in the future of the global financial market place. As the two recapitalization case studies detailed in Part V. below suggest, they have begun to develop new tri-partite arrangements aimed at stabilizing large financial intermediaries and through them global financial market place. In the absence of effective supranational regulations, joint stakeholding has become the primary mode of governing global finance. At times, this takes the form of co-ownership in the same intermediary. At others, the shadow of nationalization by a home government has been enough to induce responses by banks and SWFs. As a result, pre-crisis financial governance consisting of dispersed and passive share ownership and regulatory supervision by home governments of globally active financial intermediaries, has been replaced by sovereign actors with a mutual interest in the stability of the global system becoming joint stakeholders in key intermediaries. As a result, a new mode of governance for crisis management -- and potentially beyond -- has been invented.

\section{Organizational Hedging, Institutional Innovation and Change}

As discussed in the previous section, theories of networked governance suggest that network relations can enhance certainty by enabling collaborative 
problem solving in a world marred by uncertainty. Network relations can help bridge differences and can thereby facilitate the development of new institutional solutions that recombine elements from pre-existing, diverse institutions and governance regimes. The complex and messy process of institutional innovation in the context of competing and contested governance arrangements has been captured by the notion of "organizational hedging". David Stark developed this concept in the context of the transformation of property rights in the former socialist countries of Eastern Europe (Stark, 1996). He documented that during the early period of transition, enterprises in Hungary developed extensive webs of inter-firm relations centered around (former) state owned enterprises. Some of the enterprises' assets were spun off to other entities; others entered joint venture relations with domestic or foreign parties; yet others were privatized or transferred to employee ownership and control, or remained under the formal control of the parent enterprise. Many of these configurations changed over time as "networks of assets and chains of debt" were "recombined" (Stark, 1996). Stark interpreted the multifaceted recombination of assets as an attempt by actors facing substantial uncertainty about the direction and outcome of the reform process to operate across "multiple evaluative principles" (Stark, 1996). They learned how to play by the rules of an emergent market place while simultaneously adhering to established practices of state control. The ability to operate concurrently under different and changing institutions is the essence of organizational hedging. ${ }^{42}$ For the most part,

\footnotetext{
${ }^{42}$ Financial hedging as conventionally understood is also a response to uncertainties. It aims at reducing exposure to financial risk by diversifying one's portfolio or entering into transactions, such as swaps or option agreements that offset the risk of other transactions. In contrast, organizational
} 
the actors participating in these transactions simply sought short-term solutions to pressing needs. The extensive network of firm relations was the cumulative result of many actors engaging in similar search processes to reduce uncertainty in a changing environment.

Uncertainty about the rules of the game may stem from different causes. It may result from weaknesses in existing governance regimes, including weak or capricious enforcement of formal law, pending legal change, or a general weakening of state authority. It may also be triggered by uncertainty about social or business practices and behavior whether or not that behavior is grounded in law. Established practices or "regularized patterns of behavior" (Greif, 2006) may be undermined by shocks to the system or by an increase in defections from established practices in anticipation of a major change. Uncertainties about governance will affect not only how actors (individuals and organizations) organize their internal relations, but also their relation to one another. The global financial crisis that ensued in 2007 can be described as a shock to the prevailing system of global governance that called into the question the mode of governance and the continuing dominance of actors that flourished under the previous regime.

Organizational hedging strategies tend to be defensive rather than proactive. Actors scramble for certainty by trying out new strategies, including new business partners. The relations that result from this process create the figurative space within which institutional practices may be examined and recombined to develop new solutions. Whether these solutions will help shape the new rules of the game 
depends on how widely they will be followed, in particular the status of those who embrace them. Not all innovative practices will ever be institutionalized. In fact, most will not. The potential for innovation and institutional change increases when previously distinct domains are connected allowing or even forcing actors across these domains to interact in order to find solutions to common problems.

As Padgett and McLean (Padgett and McLean, 2006) have put it, "recombinant innovation in organizations is produced (...) when one or more social relations are transposed from one domain to another, mixing in use with relations already there" . An innovation can become a system-transformative invention according to Padgett et al., if and when it spreads into domains and usages beyond those from which it originated. The actors themselves may not realize that their experimentation or hedging strategy may trigger institutional change, much less that such change can at times have the potential for systemic transformation. In fact, the actual beneficiaries of what in hindsight turn out to be path-breaking institutional inventions frequently did not participate in their creation.

Padgett and McLean (2006) investigated institutional development in Renaissance Florence and showed that the partnership system, an invention that has been credited with the birth of financial capitalism, was the product of recombining traditional features of local banking with long distance trade. In the aftermath of a major political crisis local bankers were co-opted into the political system. Their newly gained access to levers of political control helped dismantle the traditional guild system, which had re-enforced specialization by sector and thus inhibited institutional change. The new alliance between merchants and bankers 
facilitated the geographic expansion of merchant banking. It engendered the diversified partnership system with geographically dispersed entities linked to the home base through stakes held in multiple partnerships. Relations among different partnerships were re-enforced by marriage ties as senior partners wed their daughters to junior partners who were entrusted to independently run far away operations.

The example illustrates important features of organizational hedging. A crisis (in this case a political crisis) precipitates a new alignment of actors (which none of them may have sought or anticipated ex ante), each endowed with their own and diverse institutional expertise. Both sides contribute institutional practices from their respective domains. Some institutional features are found helpful in addressing specific governance problems the parties now face. They are recombined, adjusted, or discarded. If and when a new set these recombinant institutions are widely followed, they become institutionalized and evolved into a new governance regime.

The situation parties faced in the wake of the collapse of the socialist system bore many of the same characteristics. For parties trying to operate in the former socialist countries the sudden announcement of a transition to a different regime called into question the governance of economic, social and political relations they were accustomed to. In this environment of uncertainty new coalitions were formed between government and non-government actors, domestic and foreign parties, inside and outside owners of firms. More than the simple transfer of legal institutions by way of legal transplants (Pistor, et al., 2000), these new relations, 
rooted in equity ties, facilitated the recombination of institutional practices and fostered the transformation of the economies (Elster, et al., 1998, Stark and Brusz, 1998).

For parties confronting the fallout from the global financial crisis in the $21^{\text {st }}$ century the situation is not much different than those of the parties in the aforementioned collapses; by all appearances, this crisis is fundamentally reshaping the global financial system. Until as a recently as 2007 Western banks dominated virtually unchallenged the global financial market place. According to a recent World Bank report, at the end of 2006 only 100 institutions controlled 79 percent of global bank assets (Worldbank, 2008). Most of these institutions were located in the global North. 70 percent of the banking system in Eastern Europe and over 40 percent of the banking system in Latin America were in the hands of relatively few large financial intermediaries, again mostly from the global North. The dominance of banks from Western Europe and North America implied the dominance of the model they espoused for organizing economic and financial relations. This model was based on the separation of the private and the public spheres; decisions about investment strategies and risk allocation firmly vested in private hands; and regulatory oversight of banks based on internationally agreed principles (Basel Accords ${ }^{43}$ ) with home country responsibility for regulatory oversight and risk assumption as lender of last resort. Multilateral organizations such as the IMF and the WTO played a critical role in diffusing the model by offering policy advice based

\footnotetext{
${ }^{43}$ The Base Accords are recommendations developed by the Bank for International Settlement located in Basel, Switzerland, that set forth basic principles for the prudential regulation of banks. For details see www.bis.org.
} 
on it and by promoting the globalization of financial services inspired by the Western model of international banking (Barth, et al., 2004, Levine and Zervos, 1996).

As they confronted the first serious symptoms of the crisis the pillars of Western bank dominance, that is, globally active financial intermediaries like Citigroup, Barclays, Merrill Lynch and Morgan Stanley, reached out to SWFs from East Asia and the Middle East. ${ }^{44}$ They needed and SWFs provided these troubled banks with fresh capital injections. Both sides may have regarded these transactions as short-term solutions to an immediate need, however, with the deepening crisis it become clear that interdependent global finance required collaborative responses by actors from around the globe; in this context, the fact that the sum of all rescue transactions now linked actors (banks, governments and SWFs) that previously had operated under very different governance regimes with different risk profiles and investment strategies, become of crucial importance. It fostered the realization that banks, SWFs as well as the banks' home governments had become joint stakeholders in the future of the financial system. The diversity of parties involved and their respective governance backgrounds expanded the range of governance expertise from which solutions could be constructed. As the accounts of institutional innovation by Stark, Padgett and McLean as well as Burt's theory of structural holes suggest, institutional innovation often results from interfacing players that previously operated in different domains. The need to find solutions to common problems can mobilize problem-solving strategies not available to actors that share

\footnotetext{
${ }^{44}$ According to available press reports, most investments were initiated by Western banks, not SWFs.
} 
identical institutional domains. The resulting recombinant institutions may affect not only the relation among actors that created them, but may become institutionalized as other actors begin to emulate them.

\section{GNF at Work: Two Case Studies}

The preceding sections have developed the framework for analyzing GNF not only as a way of organizing economic relations, but as an incubator for institutional change and thus new modes of governing the global financial market place. This section applies this framework to two cases that illustrate different approaches for solving the problem of bank re-capitalization as a means of stabilizing individual banks and through them, the financial system. In each case Western banks, their home-country governments, and SWFs were implicated. In one case, the bank and SWFs collaborated to keep the home country government at bay as potential coowner, while still complying with capitalization requirements the government imposed. In the other, the government was already a co-owner of the bank and the SWF agreed to make concession to improve the capital base and thereby stabilize the bank. The first case concerns Barclays, the UK government, and a consortium of sovereign investors from the Middle East. The second case centers on Citibank and its re-capitalization under the stewardship of the US government, but supported by the Government of Singapore Investment Corporation (GIC) a Saudi-Arabian investor. 


\section{Barclays, SWFs, and the UK Government}

Of the five largest British banks (HSBC, RBS, HBOS, Lloyds and Barclays) only HSBC and Barclays have so far escaped the crisis without major capital injection from the UK government. After the fall of Lehmann Brothers in September of 2008 banks around the world came under pressure to improve their capital base. Barclays faced the choice between accepting UK government bailout money or turning to SWFs. It chose the latter even though it had to overcome resistance from existing shareholders.

The UK government was the first government to offer a comprehensive government bailout plan for its largest banks in the midst of the crisis. ${ }^{45}$ The capital injections offered were conditioned, among others, on the receiving banks not paying dividends until the government loans had been paid back; curbing payments to their executives; and on a greater focus on UK as opposed to foreign financial markets. ${ }^{46}$ Barclays declined to take advantage of this rescue package, which would have allowed it to raise capital from the government in the form of loans, preferred stock, or ordinary common stock; instead, with the approval of the British Financial Service Authority (FSA) it devised a plan to raise $£ 7$ billion in a private placement of securities with selected SWFs from the Middle East, namely Qatar Holding, Challenger (an investment vehicle owned by the Royal Family of Qatar), and Sheikh Mansour Bin Zayed al Nahyan, a member of the Royal Family of Abu Dhabi. Because Barclays was able to improve its capital base, this plan will allow it to access-if

\footnotetext{
45 "Rescue plan for UK banks unveiled", BBC News 8 October 2008, available at http://news.bbc.co.uk/2/hi/business/7658277.stm.

46 Ibid
} 
necessary—the government's new loan facility for banks, the "Special Liquidity Scheme" announced in April 2008.47 Unlike a UK government bail-out, the SWF consortium did not impose constraints on dividend payments to existing shareholders or make explicit demands on bank strategies.

The scheme raised serious opposition from investors who were asked to waive their preemptive rights and whose existing holdings were severely diluted as the transaction added 36 percent to Barclays' outstanding shares. Specifically, the plan envisioned the issuance of interest bearing "reserve capital instruments" with a coupon rate of 14 percent, warrants with an option to subscribe to newly issued ordinary stock, and mandatorily convertible notes to the investors mentioned above. After these instruments were converted into ordinary shares in June 2009, Qatar Holding owned 12.8 percent in Barclays (up from 6.2 percent), and Challenger 2.8 percent. Sheikh Mansour Bin Zayed al Nahyan was to hold 16.5 percent $^{48}$ however, he sold the stake prior to the conversion date. ${ }^{49}$ Even with the departure by Sheikh Mansour, this marks an important break from Barclays' highly dispersed capital structure prior to the onset of the crisis. ${ }^{50}$ By the admission of the board, the direct costs of this financing scheme also exceeded the costs of a comparable capital injection package other banks received from the UK government.

\footnotetext{
${ }^{47}$ For details see http://www.bankofengland.co.uk/markets/sls/index.htm.

${ }^{48}$ Letter by Marcus Agius, Chairman Barclays PLC, to shareholders accompanying the notice of the General Meeting of Barclays on 24 November 2008, available at www.investorrelations.barclays.co.uk

${ }^{49}$ Andrew England and Simeon Kerr, "Shrewd sheikh on a roll", The Financial Times, 6 June 2009,7. Note that in response to this "defection" rumours spread that Barclays may, after all, require UK government support. This indicates how mutually dependent are the actions of members of GNF. ${ }^{50}$ When Qatar holding acquired a 6 percent stake in 2007, it became the largest shareholder of the bank.
} 
Barclays' board justified its support for the SWF transaction on three grounds. First, raising capital on the market under prevailing conditions was marred by uncertainties about investors' willingness and ability to commit amounts that were needed and would have come at a substantial cost premium to the bank. Second, the board believed that accepting government funding would have had an "adverse effect on the Company's flexibility to pay dividends" and would have imposed the additional cost by influencing Barclays "strategic direction" with respect to UK lending and the bank's stated objective of diversifying its geographical sources of earning:

The role of the Board is to protect the interests of shareholders and to create the circumstances in which, over time, it can maximize value on their behalf. The Board believes its ability to do this would be reduced if the Government were a major shareholder in Barclays. ${ }^{51}$

After first voicing opposition to the plan, shareholders ended up approving it, thereby joining the board in its assessment that UK government influence over the bank posed a greater threat than that of sovereign investors from Qatar or the UAE. The deal with the Qatar consortium also helped Barclays survive further stress tests the UK conducted in the spring of 2009 , allowing it to decline a new insurance program the government had devised for vulnerable banks. ${ }^{52}$

In effect, this arrangement created a new tri-partite governance structure for a globally active financial player comprised of increasingly marginalized private investors, Middle Eastern SWFs as backstop investors, and the UK government as

\footnotetext{
${ }^{51}$ Supra, note 45 at 5.

${ }^{52}$ Jon Menon, "Barclays passes FSA test, may not need more capital", 27 March 2009, available at www.bloomberg.com. See also Jeremy Warner, "FSA finds that Barclays is telling the truth", The Independent, 28 March 2009, available at www.independent.co.uk.
} 
regulator and liquidity provider of last resort. As a bank registered and licensed in the UK Barclays is subject to UK regulatory supervision, regardless of its ownership structure. Indeed, the capital increase in November was motivated by regulatory requirements to boost capital at a par with banks that received UK government funding in order to allow Barclays to access the government's liquidity scheme at a future date should the case arise. Private investors proved unreliable in times of crisis. A public placement of shares in June 2008 remained under-subscribed and most of the shares were ultimately placed with SWFs. ${ }^{53}$ When the bank needed to attract additional capital in the fall of 2008, Barclays was wary about trying again; instead, the company chose to enter into a pre-packaged deal with SWFs; for this to succeed, it had to convince existing shareholders to waive their preemptive rights and approve the transaction. This put the Middle Eastern investors in tension with other shareholders who voiced their discontent at the shareholder meeting in April 2009 when 16 percent of them rejected the re-election of Marcus Agius, the chairman of the board who had engineered the transaction. ${ }^{54}$ This, however, had little impact as the relative influence of Barclays' traditional capital base, i.e. small, dispersed shareholders, had declined with the arrival of the sovereign stakeholders.

At first glance, the relations and tensions among various stakeholders in Barclays look familiar. Minority investors are concerned about loosing their preemptive rights and a possible change in control. Regulators are concerned about

\footnotetext{
${ }^{53}$ Sean Ferrell, "Barclays' $£ 4$ bn share offer falls flat - only 19 pct sold", The Independent, 22 June 2008 , available at www.independent.ie. See also Simon Evans, "Overseas investors offer $€ 4 \mathrm{bn}$ injection to boost Barclays", The Independent, 22 June 2008, available at www.independent.co.uk. ${ }^{54}$ Tom Bawden, "Barclays revolt fuelled by shareholder anger", The Times, 24 April 2009, available at http://business. timesonline.co.uk.
} 
the viability of financial intermediaries and change regulatory standards in response to crises. However plausible, such an interpretation is incomplete, because it neglects the fact that the financial crisis has altered the relation between governments and banks, and by implication between governments as the banks' investor of last resort and other investors. This new relation implies not only that the government will monitor banks more closely, but also that a conversion from implicit to explicit government ownership has become more likely. Recent bailout transactions suggest that governments can and do extract substantial concessions from shareholders. While SWFs may not favor this prospect ${ }^{5}$ they are even less willing to replace the home country as investor of last resort for failing banks. Their relation with the banks' home government can therefore be described as one of mutual dependence.

This mutual dependence is re-enforced by the fact that -- apart from the bank's home governments -- SWFs have emerged as the only investors willing to invest substantial resources in large financial intermediaries in times of crisis . In fact, some SWFs have more liquid assets available relative to their exposure to vulnerable banks than the banks' home governments do. As suggested by some commentators, in the case of the UK the total amount of losses in the financial sector may well exceed the government's financial capabilities. ${ }^{56}$ Moreover, SWFs seem to have greater flexibility to use their disposable assets, because they are less politically constrained. After all, most of the SWFs that participated in the financial

\footnotetext{
${ }^{55}$ Note, however, that a representative of Temasek indicated that they were largely indifferent about government ownership as long as it was well managed. Interview notes on file with the author. ${ }_{56}$ Alistair MacDonald and Lauren Norman, "Bank Bailouts, Sinking Revenue Frail UK's Ledger", The Wall Street Journal, 20 February 2009, available at www.online.wsj.com.
} 
deals are from countries with autocratic forms of government (Beck and Fidora, 2008). This does not mean that they are immune from political backlash. Even China's SWF faced open criticism about the losses they suffered as a result of investing prematurely in Western banks (Zhang and He, 2009). Yet these protests pale against the hostility of voting taxpayers and their elected representatives about infusing more taxpayers' money into the financial sector in democracies; somewhat ironically, these democratically elected governments had to shed their initial skepticism, if not outright hostility against SWF as major owners of their financial institutions given their own political and financial constraints. ${ }^{57}$

Citigroup, the US Government, and GIC etc.

In the second recapitalization case the bank in question was Citigroup, which, until recently, was the largest bank in the world by assets. ${ }^{58}$ Its' rapid accumulation of asset-backed securities in the years leading up to the crisis fueled the bank's decline when the crisis unfolded. Citigroup first turned to SWFs to shore up its capital base and secured investments amounting to over US $\$ 20$ billion dollars from the ADIA of Abu Dhabi, GIC of Singapore, and HRH Prince Alwaleed Bin Talal Bin Abulaiziz Alsaud of Saudi Arabia as well as from the Kuwait Investment Authority, KIA. When Citigroup's finances deteriorated further, the US government provided a

\footnotetext{
57 The poison pill provision in the Barclays deal could be read to suggest that this still falls short of cooperation. However, the relevant provision was designed to protect only against the short term risk of dilution prior to the conversion date for convertible securities held by Abu Dhabi. In a recent trip to the Gulf States the UK's Business Secretary Mandelson confirmed the UK's openness to SWF investment and consulted with several representatives of SWFs in the region. See Stanley Carvalho, UK open to investment from SWF, Arabian business.com, 8 April 2009.

${ }^{58}$ See supra note 17.
} 
capital injection of US $\$ 25$ billion taking interest bearing preferred stock in return. It added another US $\$ 20$ billion in November 2008.59

In February 2009, the US government intervened once more, this time pressing the bank to improve its financial situation by cutting back on dividend and interest payment on preferred and convertible securities and thus enhancing its' 'tangible' common equity. ${ }^{60}$ To this end, the US government offered to convert up to US $\$ 25$ billion of the preferred stock it held at a conversion price of US $\$ 3.25$ on the condition that other 'private' investors would do the same. No money changed hands, but the conversion implied that other major preferred stock holders had to forego their dividend payments in return for common stock that gave them greater upside potential, but less protection against downside risk. Nonetheless, SWFs largely fell in place and agreed to the conversion. When announcing that GIC would follow the US government's lead, its chairman -- former president and founder of Singapore Lee Kwan Yew -- admitted that GIC had invested in Citi too early. Still, he reiterated his conviction that, in the long term, these investments would pay off.61 GIC had to give up the guaranteed 7 percent dividend agreed to in the original

\footnotetext{
${ }^{59}$ Dan Wilchins and Jonathan Stemple, "Citigroup gets massive government bailout", Reuters, 24 November 2008, available at www.reuters.com. ${ }^{60}$ See announcement of the US Treasury, "Treasury announces participation in Citigroup's exchange offering", 27 February 2009, available at www.ustreasury.gov. The conversion was motivated by a change of policy about how to properly assess the capital adequacy of banks. While preferred stock in principle qualifies as "Tier 1" capital in accordance with Basel Capital Accord of 1988 (see http://www.bis.org/publ/bcbsc111.pdf for details), the crisis has pushed policy makers to place greater weight on common stock, or what is referred to as "tangible common equity", or TCE. Unlike preferred stock, TCE does not carry mandatory dividends and thus does not reflect claims (liabilities) on the bank. For an analysis of the US Tresury's decision to convert its stake in Citigroup from preferred to common stock, see Tracy Alloway, "US U-turn on tangible common equity", 23 February 2009, available at www.ft.com/alphaville.

${ }^{61}$ John Burton, "Singapore sovereign fund invested 'too early' in Citigroup and UBS", The Financial Times, 5 March 2009, available at www.ft.com.
} 
transaction. In return, it was able to reduce the paper loss of this investment. ${ }^{62}$ Alwaleed Bin Talal of Saudi Arabia followed suit and converted its preferred stock on the same terms. In contrast, ADIA, the SWF from UAE, retained its convertible debt securities, which pay 11 percent in quarterly interest payments on US\$7.5 billion the fund invested in 2007.63 Technically, these debt instruments do not fall within the parameters of the recapitalization scheme, as they are debt instruments, not preferred stock. Nonetheless, according to press reports ADIA has been in negotiations with the US government over their mutual interests in Citigroup, albeit both sides declined to comment on whether ADIA would be willing to alter the terms of its original investments. ${ }^{64}$

The US government led recapitalization of Citigroup in February 2009 signifies an important shift not only in how Citigroup is governed, but in the role of the US government vis-à-vis Citigroup and the bank's other major investors. The US government used its leverage as investor of last resort to renegotiate the deals between Citigroup and its largest investors. It acted more like a lead creditor in a bankruptcy reorganization than co-investor-much less like an arms-length regulator; as a result of these transactions, the US government will own 34 percent common (voting) stock in Citigroup, followed by GIC with 11 percent. Small shareholders have been seriously diluted; in contrast to the Barclays deal, they did not even have to approve the transaction, as Citigroup issued pre-approved stock

\footnotetext{
${ }^{62}$ Conrad Tan, "GIC cuts loss in one fell swoop", The Business Times, 2 March 2009, available at www.asiaone.com.sg.

${ }^{63}$ Wayne Arnold, "Latest Citi bailout bypasses ADIA", The National, 28 February 2009, available at www.thenational.ae.

${ }^{64}$ Ibid. On the terms of this investment, see above text accompanying footnote 25.
} 
and received exemption from NYSE listing rules, which require shareholder approval requirement when a company issues more than 20 percent of new stock (Citigroup issued 36\% as part of this transaction). ${ }^{65}$

Some important differences between the Barclays and Citigroup deals notwithstanding, they share important features. In both cases, the interests of ordinary shareholders were curtailed substantially. Moreover, two ore more sovereign stakeholders ended up determining the fate of both banks, namely SWFs and the banks' home government in the role of a regulator and/or that of the owner. In the case of Barclays, the UK government was not directly involved in the transaction; however, it did approve of it and allowed Barclays to pass subsequent stress tests without imposing additional insurance requirements and without closing the door to its liquidity scheme. In the case of Citigroup, the US government was deeply involved in designing the transaction; it played the role of largest stakeholder, regulatory, and deal broker to ensure that other investors participated in the scheme. While there is no evidence that the US Treasury negotiated directly with GIC or one of the other sovereign investors, it is unlikely that the US would have announced the conditional conversion of its own stake without some assurance that the plan would indeed be implemented; as a result of the conversion, the US Treasury—as well as major SWFs—now have voting rights in Citigroup. The re-capitalization and thus the survival of Citigroup would have been impossible without the intervention of SWFs and the US Treasury. By the same token, their

\footnotetext{
${ }^{65}$ See "Citi files registration statement for exchange offer", available at www.citigroup.com/citi/press. The relevant rule is Section 312(c)(1) of the NYSE listing rules available at http://www.nyse.com/regulation.
} 
actions have substantially altered the governance structure of the bank by making explicit the role of the US government and SWFs as joint stakeholders in the future of this global financial intermediary.

How substantial this change is may be gauged by comparing this arrangement with the agreement the US Treasury reached with SWFs from Singapore and Abu Dhabi in March 2008 - incidentally the same parties that were involved in the 2009 re-capitalization scheme. ${ }^{66}$ SWFs committed to base their investment decisions "solely on commercial grounds, rather than to advance, directly or indirectly, the geopolitical goals of the controlling government"; to have "strong governance structures, internal controls, and operational and risk management systems"; and that "SWFs and the private sector should compete fairly". ${ }^{67}$ Conversely, the US Treasury committed "not to erect protectionist barriers to portfolio or foreign direct investment", and to "respect investor decisions by being as un-intrusive as possible, rather than seeking to direct SWF investment". 68 The language of the agreement assumes well-functioning capital markets and the clear separation of commerce and [geo]politics. Luckily for the US government, the SWFs were flexible enough not to hold it to this accord, but have come to the rescue of Citigroup even though this investment may well have been unsound on a purely commercial basis. Finally, the deal also confirms that the US government has morphed from an arms length regulator and neutral bystander of investment decisions and committed not to intrude just because the investors were SWFs, into a

66 "Treasury reaches Agreement on Principles for Sovereign Wealth Fund Investment with Singapore and Abu Dhabi", March 20, 2008, available at www.ustreas.gov/press.

${ }^{67}$ Ibid.

${ }^{68}$ Ibid. 
participant and broker of deals with SWFs in order to secure the survival of one of its leading banks. The formal features of these transactions are familiar. They entail the issuance of common stock, conversion of preferred stock and exemptions from regulatory requirements. Yet this familiarity could easily mask the identity of the parties and the tacit agreement among them that only jointly could they rescue a major financial player whose failure would have had major repercussions for the global financial system on which they all depend.

\section{Concluding Comments}

This paper has pursued two goals: to explain an empirical puzzle, and to assess its implications for the governance of global financial markets. The paper described and analyzed the emergence of a financial network that connects many of the world's largest financial intermediaries via equity links. This pattern is puzzling in light of the widely anticipated convergence of financial market governance on the Anglo-Saxon model characterized by dispersed ownership, autonomous private actors, and arms-length government regulation. Instead, we observe joint stakeholdings by Western banks and Eastern SWFs in some of the largest globally active financial intermediaries. The paper suggests that while each transaction can be explained in simple financial terms (albeit with hindsight ill-fated ones), the cumulative effect of similar transactions undertaken in close proximity warrants additional investigation and explanations. Based on organizational theories the paper suggests that the emergent network of equity patterns among diverse players 
has fostered the emergence of new governance responses to the challenges posed by the crisis. The joint stake-holdings in major financial intermediaries by sovereign investors, including their home governments and SWFs has at least temporarily become the new mode of global financial governance. Building on recent research in economic sociology, the paper also suggested that GNF has the potential of breeding further institutional experimentation and change. Two case studies were presented to illustrate that network members do indeed engage in cooperative behavior and develop new governance solutions. This does not mean that the specific configuration of GNF depicted in Figure 1 will remain unchanged. To the contrary, observing and analyzing changes to the network, in particular exit and entry decisions and clustering around key players may give clues about where to search for actor driven governance solutions. Ongoing changes in the network configuration may be read as suggesting that GNF is only a temporary solution and will dissolve once the crisis has been overcome. In light of the fact that the crisis is not over yet, the paper makes no claim about the sustainability of specific network relations in the post crisis environment. Two points are, however, worth making. First, global financial interdependence requires much more coordinative governance responses than existed prior to the crisis. GNF may not be the final solution, but offers one possible answer to this challenge. Second, the extensive use of networked responses to the financial crisis is likely to have ex ante implications for the future behavior of financial intermediaries and their sovereign stakeholders, whether home governments or SWFs - as well as their relation to each other. In 
other words, GNF is likely to cast a long shadow even if it will not survive in its current incarnation.

REFERENCES:

1. Alberola, E., and Serena, J. M., 2008. Sovereign External Assets and the Resilience of Global Imbalances. Banco de Espana, Madrid.

2. Aoki, M., 2001. Toward a Comparative Institutional Analysis. Cambridge University Press, Cambridge, MA.

3. Barth, J. R., Caprio, G. J., and Levine, R., 2004. Bank Regulation and Supervision: What Works Best? Journal of Financial Intermediation 13, 205248.

4. Bearden, J., Atwood, W., Freitag, P., Hendricks, C., Mintz, B., and Swartz, M., 1975. The nature and extent of bank centrality in corporate networks, Annual meeting of the American Sociological Association, San Francisco.

5. Bebchuk, L., and Roe, M., 1999. A Theory of Path Dependence in Corporate Governance and Ownership. Stanford Law Review 52, 127-170.

6. Bebchuk, L. A., 1999. A Rent-Protection Theory of Corporate Ownership and Control. NBER Working Paper Series 7203.

7. Bebchuk, L. A., 2002. Ex Ante Costs of Violating Absolute Priority in Bankruptcy. Journal of Finance 57, 445-460.

8. Bebchuk, L. A., Kraakman, R., and Triantis, G. G., 2000. Stock Pyramids, CrossOwnership, and Dual Class Equity: The Mechanisms and Agency Costs of Separating Control from Cash-Flow Rights. In: Morck, R. K., (Ed., Concentrated Corporate Ownership. The University of Chicago Press, Chicago and London, pp. 295-318.

9. Beck, R., and Fidora, M., 2008. The Impact of Sovereign Wealth Funds on Global Financial Markets, Occasional Papers. European Central Bank, Frankfurt.

10. Burt, R., 1995. Structural Holes: The Social Structure of Competition. Harvard University Press.

11. Coase, R. H., 1937. The Nature of the Firm. Economica, 386-405.

12. Davidoff, S. M., and Zaring, D., 2008. Big Deal: The Government's Response to the Financial Crisis. ssrn.com. 
13. Elster, J., Offe, C., and Preuss, U. K., 1998. Institutional Design in Postcommunist Societies: Rebuilding the Ship at Sea. Cambridge University Press, Cambridge, UK.

14. Franks, J., Mayer, C., and Rossi, S., 2003. The Origination and Evolution of Ownership and Control. CEPR Discussion Paper 3822.

15. Gelpern, A., 2008. The Sovereign Wealth Turn. unpublished MS on file with author.

16. Gerard, K. M., and Sauvant, K., 2009. What do we Know about state-controlled entities, and espeically Sovereign Wealth Funds? In: Sauvant, K., and Sachs, L., (Eds.), FDI by State Controlled Entities, New York.

17. Gilson, R. J., 2001. Globalizing Corporate Governance: Convergence of Form or Function. American Journal of Comparative Law 329-357.

18. Gilson, R. J., 2006. Controlling Shareholders and Corporate governance: Complicating the Comparative Taxonomy Harard Law Review 119, 1641.

19. Gilson, R. J., and Milhaupt, C. J., 2008. Sovereign Wealth Funds and Corporate Governance: A Minimalist Solution to the New Mercantilism. Stanford Law Review 60, 1345-1369.

20. Gilson, R. J., Sabel, C. F., and Scott, R. E., 2009. Contracting for Innovation: Vertical Disintegration and Interfirm Collaboration. Columbia Law Review (forthcoming).

21. Gordon, J., and Roe, M., 2004. Convergence and Persistence in Corporate Governance. Cambridge University Press, Cambridge.

22. Granovetter, M., 1973. The Strength of Weak Ties. American Journal of Sociology 78, 1360-1380.

23. Granovetter, M., 1983. The Strength of Weak Ties: A Network Theory Revisited. Sociological Theory 1.

24. Granovetter, M., 1994. Business Groups. In: Smelser, N. J., and Swedberg, R., (Eds.), The Handbook of Economic Sociology. Princeton University Press, Princeton, N.J., pp. 453-475.

25. Greif, A., 2006. Institutions and the Path to the Modern Economy: Lessons from Medieval Trade (Political Economy of Institutions and Decisions). Cambridge University Press, Cambridge.

26. Grossman, S. J., and Hart, O. D., 1986. The Costs and Benefits of Ownership: A Theory of Vertical and Lateral Integration. Journal of Political Economy 94, 691-719.

27. Gulati, R., 1998. Alliances and Networks. Strategic Management Journal 19, 293-317.

28. Hammer, C., Kunzel, P., and Petrova, I., 2008. Sovereign Wealth Funds: Current Institutional and Operational Practices. IMF Working Paper 08.

29. Hart, O., 1995. Firms, Contracts, and Financial Structure. Clarendon Press, Oxford.

30. IMF, 1995. International Capital Markets, Developments, Prospects and Policy Issues. International Monetary Fund, Washington, D.C.

31. IMF, 2003. International Standards: Strengthening Surveillance, Domestic, Institutions, and International Markets. International Monetary Fund, Washington. 
32. Khanna, T., 2000. Business Groups and Social Welfare in Emerging Markets: Existing Evidence and Unanswered Questions. European Economic Review 44, 748-761.

33. Khanna, T., and Palepu, K., 2000. Emerging Market Business Groups, Foreign Investors, and Corporate Governance. In: Morck, R. K., (Ed., Concentrated Corporate Ownership. University of Chicago Press, Chicago, pp. 265-294.

34. Kindlegerber, C., 2005. Mania, Panics, and Crashes: A History of Financial Crises. Wiley.

35. Leff, N. H., 1978. Industrial Organization and Entrepreneurship in the Developing Countries: The Economic Groups. Economic Development and Cultural Change 26, 661-675.

36. Leigh, L., and Podpiera, R., 2006. The Rise of Foreign Investment in China's Banks - Taking Stock. IMF Working Paper 2006.

37. Levine, R., and Zervos, S., 1996. Capital Control Liberalization and Stock Market Development. World Bank, Washington, D.C.

38. Monitor, 2008. Assessing the Risks: The Behaviors of Sovereign Wealth Funds in the Global Economy. Monitor Group, New York.

39. Morck, R. K., 2000. Concentrated Corporate Ownership. University of Chicago Press, Chicago.

40. North, D. C., 1990. Institutions, Institutional Change, and Economic Performance. Cambridge University Press, Cambridge; New York.

41. Padgett, J. F., and McLean, P. D., 2006. Organizational Invention and Elite Transformation: The Birth of Partnership Systems in Renaissance Florence. American Journal of Sociology 11.

42. Pistor, K., 2009. Banking Reforms and Bank Bail Outs in the Chinese Mirror. In: Stiglitz, J., (Ed., China's Transition to a Market Economy. Oxford University Press, Oxford.

43. Pistor, K., Raiser, M., and Gelfer, S., 2000. Law and Finance in Transition Economies. The Economics of Transition 8, 325-368.

44. Powell, W. W., 1990. Neither market nor hierarchy: Network form of organization. Research in Organizational Behavior 12, 295-336.

45. Prasad, E., Rajan, R., and Subramanian, A., 2007. Foreign Capital and Economic Growth. Brookings Papers on Economic Activity.

46. Robinson, D. T., and Stuart, T. E., 2002. Just How Incomplete Are Incomplete Contracts? Evidence from Biotech Strategic Alliances, Working Paper. Columbia University, New York.

47. Roe, M. J., 1993. Some Differences in Corporate Structure in Germany, Japan, and the United States. Yale Law Journal 102, 1927-2003.

48. Sabel, C., and Zeitlin, J., 2006. Learning from Difference: The New Architecture of Experimentalist Governance in the European Union. Unpublished working paper.

49. Seligman, J., 1983. The Historical Need for a Mandatory Corporate Disclosure System. Journal of Corporation Law 9, 1-61.

50. Shin, J.-S., and Chang, H.-J., 2005. Economic Reform After the Financial Crisis: A Critical Assessment of Institutional Transition and Transition Costs in South Korea. Review of International Political Economy 12, 409-433. 
51. Shleifer, A., and Vishny, R. W., 1997. A Survey of Corporate Governance. The Journal of Finance LII, 737-783.

52. Stark, D., 1996. Recombinant Property in East European Capitalism. American Journal of Sociology 101.

53. Stark, D., and Brusz, L., 1998. Postsocialist Pathways: Transforming Politics and Property in East Central Europe. University of Cambridge Press, Cambridge, UK.

54. Williamson, O. E., 1985. The Economic Institutions of Capitalism: Firms, Markets, Relational Contracting. Free Press; London: Collier Macmillan, New York.

55. Worldbank, 2008. Global Development Finance: The Role of International Banking. The World Bank, Washington, D.C.

56. Zhang, M., and He, F., 2009. China's Sovereign Wealth Fund: Weaknesses and Challenges. China \& World Economy 17, 101-116. 


\section{Appendix 1: Transactions between Banks, SWFs and Governments}

\begin{tabular}{|c|c|c|c|c|c|c|}
\hline $\begin{array}{l}\text { FOREIGN } \\
\text { BANK }\end{array}$ & DATE* & SWF/ GcFE & $\begin{array}{l}\text { VALUE } \\
\text { US\$ } \\
\text { (BN) }\end{array}$ & $\begin{array}{l}\text { STAKE } \\
(\%)\end{array}$ & DEAL FEATURES & $\begin{array}{l}\text { SUBSEQUENT } \\
\text { DEVELOPMENTS/COMMENTS }\end{array}$ \\
\hline $\begin{array}{l}\text { Blackstone } \\
\text { (US) }\end{array}$ & $5 / 2007$ & CIC/China & 3.0 & 9.9 & $\begin{array}{l}\text { Non-voting units in } \\
\text { limited partnership; } \\
\text { 10\% ceiling; } 3 \text {-year } \\
\text { lock-in \& +3 year } \\
\text { divestiture period }\end{array}$ & $\begin{array}{l}\text { Increased to } 12.5 \text { percent } \\
\text { in } 10 / 2008\end{array}$ \\
\hline Apollo (US) & $7 / 2007$ & Abu Dhabi & & 10 & & \\
\hline \multirow[t]{7}{*}{$\begin{array}{l}\text { Barclays } \\
\text { (UK) }\end{array}$} & $6 / 2007$ & $\begin{array}{l}\text { Qatar } \\
\text { Investment } \\
\text { Authority }\end{array}$ & 3.5 & 6.42 & $\begin{array}{l}\text { Common stock by } \\
\text { exercising pre-sold } \\
\text { rights issues }\end{array}$ & \\
\hline & $6 / 2007$ & $\begin{array}{l}\text { Challenger } \\
\text { (asset } \\
\text { manager of } \\
\text { Qatar royal } \\
\text { family) }\end{array}$ & & 1.92 & Common stock & \\
\hline & $7 / 2007$ & Temasek & & 2.6 & Common stock & $\begin{array}{l}6 / 2008 \text { additional } \\
\text { investment in private } \\
\text { placement after IPO is } \\
\text { under-subscribed }\end{array}$ \\
\hline & & & & & & 6/2009 stake sold \\
\hline & $7 / 2007$ & $\begin{array}{l}\text { China } \\
\text { Development } \\
\text { Bank }\end{array}$ & & 3 & Common stock & $\begin{array}{l}6 / 2008 \text { additional } \\
\text { investment in private } \\
\text { placement after IPO is } \\
\text { under-subscribed }\end{array}$ \\
\hline & $11 / 2008$ & $\begin{array}{l}\text { SAFE, China } \\
\text { Royal Family } \\
\text { Abud Dhabi }\end{array}$ & 16.5 & $>1$ & $\begin{array}{l}\text { Common stock } \\
\text { Convertible } \\
\text { securities }\end{array}$ & $\begin{array}{l}\text { Sold prior to conversion } \\
\text { into common stock in } \\
6 / 2009\end{array}$ \\
\hline & $11 / 2008$ & $\begin{array}{l}\text { Challenger \& } \\
\text { QIA etc. }\end{array}$ & 12 & & $\begin{array}{l}\text { Convertible } \\
\text { securities }\end{array}$ & \\
\hline $\begin{array}{l}\text { Standard } \\
\text { Chartered } \\
\text { (UK) }\end{array}$ & $8 / 2007$ & Temasek & & 11 & Common stock & Increased to 19 percent \\
\hline $\begin{array}{l}\text { Carlyle } \\
\text { Group } \\
\text { (US) }\end{array}$ & $9 / 2007$ & $\begin{array}{l}\text { Mubadala } \\
\text { Group } \\
\text { Abu Dhabi }\end{array}$ & 1.35 & & $\begin{array}{l}7.5 \% \text { equity stake; } \\
\text { floor guaranteed }\end{array}$ & \\
\hline \multirow[t]{3}{*}{$\begin{array}{l}\text { Citigroup } \\
\text { (US) }\end{array}$} & $11 / 2007$ & $\begin{array}{l}\text { Abu Dhabi } \\
\text { ADIA }\end{array}$ & 7.5 & & $\begin{array}{l}4.9 \% \text { convertible } \\
\text { units at } 11 \% \\
\text { interest }\end{array}$ & \\
\hline & $11 / 2007$ & $\begin{array}{l}\text { Kuwait } \\
\text { Investment } \\
\text { Authority }\end{array}$ & 3 & & $\begin{array}{l}2 \% \text { optional } \\
\text { convertible } \\
\text { preferred stock; } 9 \% \\
\text { dividend }\end{array}$ & $\begin{array}{l}05 / 2009 \text { converted to } \\
\text { common stock }\end{array}$ \\
\hline & & $\begin{array}{l}\text { Prince Saudi } \\
\text { Arabia }\end{array}$ & & & & $\begin{array}{l}05 / 2009 \text { converted to } \\
\text { common stock }\end{array}$ \\
\hline
\end{tabular}




\begin{tabular}{|c|c|c|c|c|c|c|}
\hline & $1 / 2008$ & $\begin{array}{l}\text { GIC } \\
\text { (Singapore) }\end{array}$ & 6.88 & & $\begin{array}{l}3.7 \% \text { optional } \\
\text { convertible } \\
\text { preferred stock; } 7 \% \\
\text { dividend; non- } \\
\text { callable prior to } \\
\text { year } 7 ; 20 \% \\
\text { conversion } \\
\text { premium; 6-month } \\
\text { lock up }\end{array}$ & $\begin{array}{l}2 / 2009 \text { converted to } \\
\text { common stock }\end{array}$ \\
\hline \multirow{4}{*}{$\begin{array}{l}\text { UBS } \\
\text { Switzerland }\end{array}$} & $12 / 2007$ & Unidentified & & 2 & Convertible debt & \\
\hline & & $\begin{array}{l}\text { ME investor } \\
\text { (Saudi } \\
\text { Arabia) }\end{array}$ & & & $\begin{array}{l}\text { securities @ 9\% } \\
\text { interest }\end{array}$ & \\
\hline & $12 / 2007$ & $\begin{array}{l}\text { Government } \\
\text { of Singapore } \\
\text { Investment } \\
\text { Corporation } \\
\text { (GIC) }\end{array}$ & 9.7 & 8 & $\begin{array}{l}\text { Convertible debt } \\
\text { securities @ 9\% } \\
\text { interest; must be } \\
\text { converted into } \\
\text { shares within } 2 \\
\text { years }\end{array}$ & \\
\hline & $10 / 2008$ & $\begin{array}{l}\text { Swiss } \\
\text { Government }\end{array}$ & 9 & & $\begin{array}{l}\text { Capital infusion; } \\
\text { transfer of toxic } \\
\text { assets to fund co- } \\
\text { financed by UBS and } \\
\text { SNB }\end{array}$ & \\
\hline \multirow{3}{*}{$\begin{array}{l}\text { Morgan } \\
\text { Stanley } \\
\text { (US) }\end{array}$} & $12 / 2007$ & CIC/China & 5.0 & & $\begin{array}{l}\text { Convertible units @ } \\
9 \% \text { interest }\end{array}$ & $\begin{array}{l}6 / 2009 \text { increased to } 10 \\
\text { percent }\end{array}$ \\
\hline & $9 / 2008$ & $\begin{array}{l}\text { Mitsubishi } \\
\text { UFJ }\end{array}$ & 20 & & Common stock & \\
\hline & $10 / 2008$ & $\begin{array}{l}\text { US } \\
\text { Government }\end{array}$ & 25 & & Preferred stock & \\
\hline \multirow[t]{7}{*}{$\begin{array}{l}\text { Merrill } \\
\text { Lynch }\end{array}$} & $12 / 2007$ & Temasek & 4.4 & 9.4 & $\begin{array}{l}\text { Mandatory } \\
\text { convertible } \\
\text { preferred stock; } 9 \% \\
\text { interest; option to } \\
\text { buy additional } \\
\text { US } \$ 600 \text { mln worth } \\
\text { of stock }\end{array}$ & \\
\hline & $1 / 2008$ & $\begin{array}{l}\text { Kuwait } \\
\text { Investment } \\
\text { Authority }\end{array}$ & 2.0 & 3.3 & $\begin{array}{l}\text { Mandatory } \\
\text { convertible } \\
\text { preferred shares; } \\
9 \% \text { interest }\end{array}$ & \\
\hline & $1 / 2008$ & $\begin{array}{l}\text { Korean } \\
\text { Investment } \\
\text { Corporation }\end{array}$ & 2 & 3.3 & 3.3 & $\begin{array}{l}\text { Exits upon merger between } \\
\text { Merrill and BofA }\end{array}$ \\
\hline & $2 / 2008$ & Temasek & 0.6 & 1.23 & Common stock & \\
\hline & $7 / 2008$ & Temasek & 0.9 & & Common stock & $\begin{array}{l}\text { Preferred stock converted } \\
\text { into common stock under } \\
\text { MergerAgreement between } \\
\text { Merrill and BofA }\end{array}$ \\
\hline & $10 / 2008$ & $\begin{array}{l}\text { US } \\
\text { Government }\end{array}$ & 25 & & Preferred stock & \\
\hline & $12 / 2008$ & $\begin{array}{l}\text { Bank of } \\
\text { America } \\
\text { (BofA) }\end{array}$ & 100 & & Common Stock & $\begin{array}{l}\text { 12/2008 Temasek becomes } \\
\text { shareholder in Bank of } \\
\text { America } \\
5 / 2009 \text { Temasek sells } \\
\text { stake in BofA }\end{array}$ \\
\hline
\end{tabular}

*Organized by first date involving a transaction with the bank in question Source: Compiled by author from various news reports. 
Figure 1:

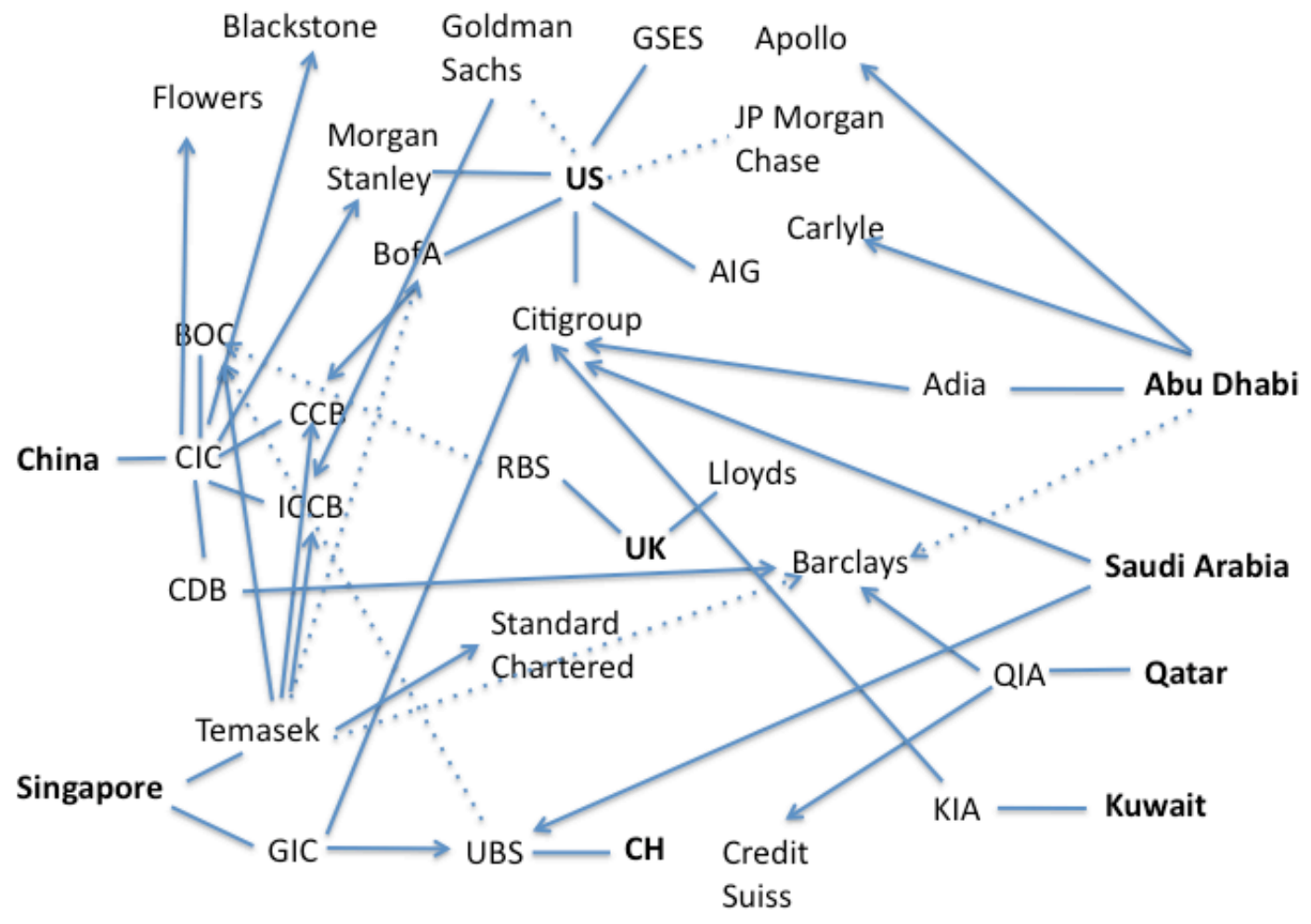

